\title{
Complete androgen insensitivity syndrome: factors influencing gonadal histology including germ cell pathology
}

Jana Kaprova-Pleskacova ${ }^{1}$, Hans Stoop ${ }^{2}$, Hennie Brüggenwirth ${ }^{3}$, Martine Cools ${ }^{4}$, Katja P Wolffenbuttel ${ }^{5}$, Stenvert LS Drop ${ }^{6}$, Marta Snajderova ${ }^{1}$, Jan Lebl ${ }^{1}$, $\mathrm{J}_{\text {Wolter Oosterhuis }}{ }^{2}$ and Leendert HJ Looijenga ${ }^{2}$

${ }^{1}$ Department of Pediatrics, Charles University in Prague, 2nd Faculty of Medicine and University Hospital Motol, Prague, Czech Republic; ${ }^{2}$ Department of Pathology, Erasmus MC, Josephine Nefkens Building, Rotterdam, The Netherlands; ${ }^{3}$ Department of Clinical Genetics, Erasmus MC, Rotterdam, The Netherlands; ${ }^{4}$ Department of Pediatrics, Division of Pediatric Endocrinology, University Hospital Ghent, Ghent University, Ghent, Belgium; ${ }^{5}$ Department of Pediatric Urology, Erasmus MC - Sophia Children's Hospital, Rotterdam, The Netherlands and ${ }^{6}$ Department of Pediatric Endocrinology, Erasmus MC - Sophia Children's Hospital, Rotterdam, The Netherlands

Patients with complete androgen insensitivity syndrome are at an increased risk for the development of gonadal germ cell cancer. Residual androgen receptor (AR) activity and abnormal gonadal location may influence the survival of atypical germ cells and the development of other histopathological features. To assess this, we evaluated 37 gonads from 19 patients with complete androgen insensitivity (ranging in age from 3 months to 18 years). Histological abnormalities were examined using hematoxylin and eosin-stained sections and sections stained for POU5F1 and KITLG, markers of early changes in germ cells at risk for malignant transformation. Hamartomatous nodules (HNs), Leydig cell hyperplasia (LCH), decreased germ cells, tubular atrophy and stromal fibrosis were more pronounced as age increased $(P<0.001)$. Expected residual $A R$ activity acted as a positive predictor only for non-malignant germ cell survival in (post)pubertal patients $(P<0.05)$. Immunohistochemical studies indicated that delayed maturation of germ cells was present in three patients, whereas intermediate changes that occurred between delayed maturation and intratubular germ cell neoplasia, designated pre-intratubular germ cell neoplasia, were identified in four cases. Intratubular germ cell neoplasia was observed in one patient. Neither POU5F1 nor KITLG expression was dependent on expected residual AR activity. An independent effect of inguinal versus abdominal position of the gonads was difficult to assess because inguinal gonads were present primarily in the youngest individuals. In conclusion, many histological changes occur increasingly with age. Expected residual AR activity contributes to better survival of the general germ cell population in (post)pubertal age; however, it did not seem to have an important role in the survival of the germ cells at risk for malignant transformation (defined by POU5F1 positivity and KITLG overexpression) in complete androgen insensitivity. Comparison of the high percentage of patients in our study that were carrying germ cells with delayed maturation or pre-intratubular germ cell neoplasia with previously reported cumulative risk of tumor development in adult patients indicates that not all such precursor lesions in complete androgen insensitivity will progress to invasive germ cell cancer.

Modern Pathology (2014) 27, 721-730; doi:10.1038/modpathol.2013.193; published online 1 November 2013

Keywords: complete androgen insensitivity syndrome; delayed germ cell maturation; gonads; intratubular germ cell neoplasia; KITLG; POU5F1

Correspondence: Dr J Kaprova-Pleskacova, MD, Department of Pediatrics, Charles University in Prague, 2nd Faculty of Medicine and University Hospital Motol, V Uvalu 84, Prague 5, 150 06, Czech Republic.

E-mail: kapr.jana@seznam.cz

Received 9 July 2013; revised 2 September 2013; accepted 2 September 2013; published online 1 November 2013
Complete androgen insensitivity syndrome is a clinical condition that is caused by an inactivating mutation in the androgen receptor (AR) gene, leading to a female phenotype in an individual with a male karyotype $(46, \mathrm{XY}) .{ }^{1}$ Typical changes in the gonadal histology of patients with complete androgen insensitivity have been described. ${ }^{2}$ These 
changes develop with increasing age and may be influenced by two major factors: abnormal gonadal location and decreased AR activity. ${ }^{2,3}$ Among others, germ cell anomalies are of crucial importance. Increased risk of germ cell cancer development has been noted in complete androgen insensitivity syndrome. ${ }^{4,5,6}$ The occurrence of germ cell cancer has been reported to be up to $22 \%$ in adult patients. ${ }^{5}$ Germ cell cancer is very rare in childhood and adolescence ${ }^{7}$ however, non-invasive precursor lesions characterized as intratubular germ cell neoplasia, also termed as carcinoma in situ of the testis, have been repeatedly described in this age group. ${ }^{2,8}$ Interestingly, the occurrence of intratubular germ cell neoplasia in pediatric patients, which is at a maximum of $6 \%$ of cases, does not reach the frequency of germ cell cancer in adulthood reported in most literature. ${ }^{2,8-11}$

The prevalence of intratubular germ cell neoplasia appears to be remarkably higher $(15 \%)$ in pediatric patients with partial androgen insensitivity than in patients with complete androgen insensitivity. ${ }^{4}$ Hannema et al described that residual activity of AR has a positive effect on the development of Wolffian structures and the enlargement of seminiferous tubules during puberty in patients with complete androgen insensitivity syndrome. ${ }^{2,12}$ Whether residual AR activity also has an impact on the survival of normal and/or atypical germ cells has not yet been reported.

The aim of the present study was to investigate the role of residual AR activity and abnormal gonadal location on the survival of atypical germ cells, as well as on the development of other histopathological changes of the testis in complete androgen insensitivity. We assessed 37 gonads of 19 patients with complete androgen insensitivity syndrome. The investigation included immunohistochemical detection of POU class 5 homeobox 1 (POU5F1, also known as OCT3/4) and KIT ligand (KITLG, also known as SCF). ${ }^{13,14}$ These two markers were only recently applied in the assessment of early changes in germ cells at risk for malignant transformation. To our knowledge, this is the first study exclusively dealing with patients with complete androgen insensitivity syndrome using both markers. In addition, the expression of testis-specific Y-encoded protein 1 (TSPY1), a candidate for gonadoblastoma locus on $\mathrm{Y}$ chromosome that is normally expressed in (pre-)spermatogonia, was investigated. ${ }^{15}$

\section{Materials and methods}

\section{Patients and Histological Material}

We investigated 37 testes from 19 Czech and Dutch patients with the complete form of androgen insensitivity syndrome, ie, patients with an unambiguously female phenotype who were diagnosed based on having AR gene mutation identified by direct sequencing in a diagnostic set up. Patients ranged in age from 3 months to 18.5 years (mean $=9.2$ years). The samples were collected between 1992 and 2005 and were included only if the activity of AR could be inferred from the sequencing results or if a reference about the functional studies existed (see below). Based on the type of mutation (frame shift mutations, mutations leading to the introduction of a stop codon after internal initiation-oftranslation sites) and a search of the literature (point mutations with zero activity in ligand-binding or transactivation studies), no residual activity of AR was expected in 11 patients. ${ }^{16-19}$ In five patients, a point mutation in the ligand-binding domain resulted in a mutated AR with some residual activity in transactivation studies. ${ }^{12,20-22}$ In the remaining three patients, the activity of AR was uncertain: mutation of an intronic region led to abnormal splicing of AR in one sibling pair, ${ }^{23}$ and AR truncated at the amino-terminal side was detected as a result of an early introduced stop-codon in the third case. ${ }^{24}$ One or both gonads were originally positioned in the inguinal region in six patients and were relocated into the abdominal cavity at hernioplasty during infancy or early childhood. Only a single gonad was situated in the labial region and was grouped with inguinal gonads for statistical analysis. The gonads were removed as a prophylactic measure in all cases (see Table 1).

This study was approved by the local Ethics Committee of the University Hospital Motol, Prague (EC 237/2009), and the samples were used according to the Code for Proper Secondary Use of Human Tissue in The Netherlands, as developed by the Dutch Federation of Medical Scientific Societies (Federa, 2011).

\section{Gonadal Histology Assessment}

All gonadal samples were fixed in 10\% formalin and embedded in paraffin. At least one section from each gonad was stained with hematoxylin and eosin and assessed by a pathologist who was experienced in gonadal histology (JWO) for overall organization of the gonadal tissue, markers of pubertal maturation, and abnormal histological phenomena. The fraction of seminiferous tubules containing germ cells was calculated in at least 200 cross-sections of tubules in each gonad.

\section{Definition of Delayed Maturation of Germ Cells, Intratubular Germ Cell Neoplasia and Pre-Intra- tubular Germ Cell Neoplasia}

Delayed maturation of germ cells is defined as the presence of POU5F1-positive germ cells with round nuclei located centrally in the seminiferous tubules of individuals over 6 months of age. Only occasionally are weakly POU5F1-positive cells at the basement membrane of the tubules accepted as 
Table 1 Patient information for age, mutation (reference sequence: hg19, NM 000044), ${ }^{31}$ expected AR residual activity and gonadal location

\begin{tabular}{|c|c|c|c|c|c|c|}
\hline & Age (years) & $\begin{array}{c}\text { Mutation nucleotide (HGVS)//amino- } \\
\text { acid level }\end{array}$ & $\begin{array}{l}\text { Expected residual AR activity } \\
\text { (method used) }\end{array}$ & Reference & Gonad & $\begin{array}{l}\text { Gonadal } \\
\text { location }\end{array}$ \\
\hline S1 & 0.25 & $\begin{array}{l}\text { c.1769-11T }>\text { A } / / \text { p.? } \\
\text { Sister of S5 }\end{array}$ & $\begin{array}{l}\text { ??? } \\
\text { TA (0\% activity with } 10 \mathrm{nM} \\
\text { R1881) }\end{array}$ & $\begin{array}{l}\text { Brüggenwirth } \\
\text { et al, } 1997\end{array}$ & $\begin{array}{l}\text { Right } \\
\text { Left }\end{array}$ & $\begin{array}{l}\text { Inguinal } \\
\text { Inguinal }\end{array}$ \\
\hline S2 & 0.80 & c. $2566 \mathrm{C}>\mathrm{T} / / \mathrm{p}$. Arg856Cys & $\begin{array}{l}\text { No } \\
\text { LBA ( } 0 \% \text { ligand-binding } \\
\text { activity) }\end{array}$ & $\begin{array}{l}\text { Weidemann et al, } \\
1996\end{array}$ & $\begin{array}{l}\text { Right } \\
\text { Left }\end{array}$ & $\begin{array}{l}\text { Inguinal } \\
\text { Inguinal }\end{array}$ \\
\hline S3 & 1.20 & c.1721C > A//p.Ala574Asp & $\begin{array}{l}\text { No } \\
\text { TA ( } 0 \% \text { activity with } 10 \mathrm{nM} \\
\text { R1881) }\end{array}$ & $\begin{array}{l}\text { Brüggenwirth } \\
\text { et al, } 1998\end{array}$ & $\begin{array}{l}\text { Right } \\
\text { Left }\end{array}$ & $\begin{array}{l}\text { Inguinal } \\
\text { Inguinal }\end{array}$ \\
\hline S4 & 1.25 & $\begin{array}{l}\text { c.1000insT//p.Gly334Valfs * } 7 \\
\text { Sister of S9 }\end{array}$ & No & & $\begin{array}{l}\text { Right } \\
\text { Left }\end{array}$ & $\begin{array}{l}\text { Inguinal } \\
\text { Abdominal }\end{array}$ \\
\hline S5 & 2.50 & $\begin{array}{l}\text { c. } 1769-11 \mathrm{~T}>\mathrm{A} / / \mathrm{p} . ? \\
\text { Sister of } \mathrm{S} 1\end{array}$ & $\begin{array}{l}\text { ??? } \\
\text { TA (0\% activity with } 10 \mathrm{nM} \\
\text { R1881) }\end{array}$ & $\begin{array}{l}\text { Brüggenwirth } \\
\text { et al, } 1997\end{array}$ & $\begin{array}{l}\text { Right } \\
\text { Left }\end{array}$ & $\begin{array}{l}\text { Inguinal } \\
\text { Inguinal }\end{array}$ \\
\hline S6 & 2.75 & c. $2343 \mathrm{G}>\mathrm{A} / / \mathrm{p} . \mathrm{Met} 781 \mathrm{Ile}$ & $\begin{array}{l}\text { Yes } \\
\text { TA (100\% activity with } 3 \mathrm{nM} \\
\text { R1881) }\end{array}$ & Knoke et al, 1999 & $\begin{array}{l}\text { Right } \\
\text { Left }\end{array}$ & $\begin{array}{l}\text { Inguinal } \\
\text { Inguinal }\end{array}$ \\
\hline S7 & 3.00 & c.178C > T //p.Gln60* & $\begin{array}{l}\text { ??? } \\
\text { TA (30\% with } 2 \mathrm{nM} \text { DHT) }\end{array}$ & Zoppi et al, 1993 & $\begin{array}{l}\text { Right } \\
\text { Left }\end{array}$ & $\begin{array}{l}\text { NA } \\
\text { Inguinal }\end{array}$ \\
\hline S8 & 3.20 & c. $2522 \mathrm{G}>\mathrm{A} / / \mathrm{p} . \operatorname{Arg} 841 \mathrm{His}$ & $\begin{array}{l}\text { Yes } \\
\text { TA ( } 60 \% \text { activity with } 2.2 \mathrm{nM} \\
\text { mibolerone) }\end{array}$ & Beitel et al, 1994 & $\begin{array}{l}\text { Right } \\
\text { Left }\end{array}$ & $\begin{array}{l}\text { labial } \\
\text { Inguinal }\end{array}$ \\
\hline S9 & 6.00 & $\begin{array}{l}\text { c. } 1000 \text { insT// p.Gly334Valfs*7 } \\
\text { Sister of S4 }\end{array}$ & No & & $\begin{array}{l}\text { Right } \\
\text { Left }\end{array}$ & $\begin{array}{l}\text { Abdominal } \\
\text { Abdominal }\end{array}$ \\
\hline S10 & 9.50 & $\begin{array}{l}\text { c. } 2197 \mathrm{G}>\mathrm{A} / / \text { Asp } 733 \text { Asn } \\
\text { Sister of S17 }\end{array}$ & $\begin{array}{l}\text { Yes } \\
\text { TA ( } 120 \% \text { activity with } 10 \mathrm{nM} \\
\text { mibolerone) }\end{array}$ & $\begin{array}{l}\text { Hannema et al, } \\
2004\end{array}$ & $\begin{array}{l}\text { Right } \\
\text { Left }\end{array}$ & $\begin{array}{l}\mathrm{i} / \mathrm{a}(1 \mathrm{y}) \\
\mathrm{i} / \mathrm{a}(1 \mathrm{y})\end{array}$ \\
\hline S11 & 13.66 & $\begin{array}{l}\text { c.832-833dupGC//p.Val279Leufs*18 } \\
\text { Sister of S18 }\end{array}$ & No & & $\begin{array}{l}\text { Right } \\
\text { Left }\end{array}$ & $\begin{array}{l}\text { i/a }(6 \text { y) } \\
\text { i/a }(6 \text { y) }\end{array}$ \\
\hline $\mathrm{S} 12$ & 15.20 & c.1847G > A//p.Arg616His & $\begin{array}{l}\text { No } \\
\text { TA ( } 0 \% \text { activity with } 10 \mathrm{nM} \\
\text { mibolerone) }\end{array}$ & $\begin{array}{l}\text { Mowszowitz et al, } \\
1993\end{array}$ & $\begin{array}{l}\text { Right } \\
\text { Left }\end{array}$ & $\begin{array}{l}\text { Abdominal } \\
\text { Abdominal }\end{array}$ \\
\hline $\mathrm{S} 13$ & 15.50 & c. $2567 \mathrm{G}>\mathrm{A} / / \mathrm{p}$. Arg856His & $\begin{array}{l}\text { Yes } \\
\text { TA ( } 80 \% \text { activity with } 2 \mathrm{nM} \\
\text { mibolerone) }\end{array}$ & $\begin{array}{l}\text { Marcelli et al, } \\
1994\end{array}$ & $\begin{array}{l}\text { Right } \\
\text { Left }\end{array}$ & $\begin{array}{l}\text { Inguinal } \\
\text { Inguinal }\end{array}$ \\
\hline S14 & 15.66 & $\begin{array}{l}\text { c. } 2546 \text { dupA A/p.Asn849Lysfs* } 32 \\
\text { Sister of S15 }\end{array}$ & No & & $\begin{array}{l}\text { Right } \\
\text { Left }\end{array}$ & $\begin{array}{l}\text { Abdominal } \\
\text { i/a }(0 \text { y) }\end{array}$ \\
\hline S15 & 15.66 & $\begin{array}{l}\text { c. } 2546 \text { dupA A/p.Asn849Lysfs*32 } \\
\text { Sister of S14 }\end{array}$ & No & & $\begin{array}{l}\text { Right } \\
\text { Left }\end{array}$ & $\begin{array}{l}\text { i/a }(0 \mathrm{y}) \\
\text { Abdominal }\end{array}$ \\
\hline S16 & 16.20 & c. $1774 \mathrm{C}>\mathrm{T} / / \mathrm{p} . \mathrm{G} \ln 592^{*}$ & No & & $\begin{array}{l}\text { Right } \\
\text { Left }\end{array}$ & $\begin{array}{l}\text { Abdominal } \\
\text { Abdominal }\end{array}$ \\
\hline S17 & 16.50 & $\begin{array}{l}\text { c. } 2197 \mathrm{G}>\mathrm{A} / / \text { Asp } 733 \text { Asn } \\
\text { Sister of S10 }\end{array}$ & $\begin{array}{l}\text { Yes } \\
\text { TA ( } 120 \% \text { activity with } 10 \mathrm{nM} \\
\text { mibolerone) }\end{array}$ & $\begin{array}{l}\text { Hannema et al, } \\
2004\end{array}$ & $\begin{array}{l}\text { right } \\
\text { Left }\end{array}$ & $\begin{array}{l}\mathrm{i} / \mathrm{a}(1 \mathrm{y}) \\
\mathrm{i} / \mathrm{a}(1 \mathrm{y})\end{array}$ \\
\hline S18 & 16.66 & $\begin{array}{l}\text { c.832-833dupGC//p.Val279Leufs*18 } \\
\text { Sister of S11 }\end{array}$ & No & & $\begin{array}{l}\text { Right } \\
\text { Left }\end{array}$ & $\begin{array}{l}\text { i/a }(3 \mathrm{y}) \\
\text { i/a }(3 \mathrm{y})\end{array}$ \\
\hline S19 & 18.50 & c.159-171del13//p.Leu54Serfs*117 & No & & $\begin{array}{l}\text { Right } \\
\text { Left }\end{array}$ & $\begin{array}{l}\text { Abdominal } \\
\text { Abdominal }\end{array}$ \\
\hline
\end{tabular}

Abbreviations: ???, unknown; i/a (x y), original location inguinal, relocated to abdominal cavity at $x$ years; LBA, ligand-binding activity; NA, not available; TA, transactivation.

indicators of delayed maturation. Such cells are considered to be in the process of turning off POU5F1 expression. KITLG is not expressed in gonads with delayed maturation germ cells. . $^{8,14}$

For the diagnosis of intratubular germ cell neoplasia, the presence of at least one cross-section of a seminiferous tubule containing a homogeneous population of atypical germ cells with angulated nuclei is required. These cells must show either homogeneous double expression of POU5F1 (nuclear) and TSPY1 (cytoplasmic and membranous) or homogenous expression of POU5F1 (nuclear) in the absence of TSPY1. The involved tubule must show expression of KITLG, which usually presents as irregular spots associated with the cytoplasm of Sertoli cells.
A diagnosis of pre-intratubular germ cell neoplasia is made when the findings fall short of the criteria for intratubular germ cell neoplasia and are beyond those that are acceptable for the diagnosis of delayed maturation. KITLG may be expressed in testes containing pre-intratubular germ cell neoplasia. ${ }^{14,25}$

\section{Immunohistochemistry}

Tissue samples from 36 gonads (22 gonads from patients with expected no AR activity; 9 gonads from patients with expected residual AR activity; 5 gonads from patients with uncertain AR activity) were available for immunohistochemical staining. After antigen retrieval $\left(120^{\circ} \mathrm{C}, 0.9 \mathrm{Bar}\right), 4-\mu$ m-thick 
sections were evaluated for the presence of POU5F1 (sc-5279, Santa Cruz Biotechnology, CA, USA, dilution 1:350, incubated for $120 \mathrm{~min}$ at room temperature) and TSPY1 (the antibody was kindly provided by Professor/Dr C. Lau, Department of Medicine, VA Medical Center, University of California, San Francisco, CA, USA; dilution 1:4000, incubated overnight at $4{ }^{\circ} \mathrm{C}$ ). POU5F1-positive samples were also stained for KITLG/SCF (sc-1302, Santa Cruz Biotechnology, CA, USA, dilution 1:250, incubated overnight at $4{ }^{\circ} \mathrm{C}$ ). Detection and visualization were conducted using biotinylated secondary antibodies and avidin-biotin complex conjugated with horseradish peroxidase for POU5F1 (Vectastain ABC kit Elite pk-6100 Standard) or alkaline phosphatase for TSPY1 and KITLG/SCF (Vectastain ABC kit pk-5000 AP). Diaminobenzidine $/ \mathrm{H}_{2} \mathrm{O}_{2}$ (for POU5F1) and New Fuchsine/Naphtol ASMX phosphate (for TSPY1 and KITLG/SCF; N500 Sigma, Steinheim, Germany) were used as substrates. Adult testicular tissue with intratubular germ cell neoplasia was used as a positive control for all staining. The proportion of POU5F1-positive cells allocated to the basal lamina was assessed on 20 crosssections of tubules, if available.

\section{Double-Staining}

Samples with POU5F1-positive cells were investigated for co-expression of POU5F1 and TSPY1. Sections were pretreated with $\mathrm{H}_{2} \mathrm{O}_{2}$, pressure cooked and incubated with primary antibodies against TSPY1 (overnight, at $4^{\circ} \mathrm{C}$ ) and POU5F1 (sc-8629, dilution 1:350, incubated for $120 \mathrm{~min}$ at room temperature). TSPY1 was detected using the avidin-biotin complex conjugated with alkaline phosphatase complex and Fast Blue/Naphtol ASMX phosphate as a substrate. POU5F1 was detected with avidin-biotin complex conjugated with horseradish peroxidase complex and 3-amino-9-ethyl-carbazole (Sigma, Steinheim, Germany) $/ \mathrm{H}_{2} \mathrm{O}_{2}$ as a substrate. In between the two stainings, free biotin was blocked (Vector Laboratories, Burlingame, CA, USA). The adult testicular tissue containing intratubular germ cell neoplasia was used as positive control.

\section{Statistics}

Influence of age, gonadal location at the time of gonadectomy, and expected level of AR activity on particular histological features were analyzed. The results were assessed using Mann-Whitney and $\chi^{2}$ tests, as well as logistic, multivariate, and linear regressions. Correlation between original gonadal location and expected AR activity was evaluated by a $\chi^{2}$ test. Correlations between expected AR activity and age and between gonadal location and age were analyzed by a Mann-Whitney test. A value of $P<0.05$ was considered significant. All analyses were performed using SYSTAT 10.0.

\section{Results}

The original anatomical gonadal location was significantly dependent on expected AR activity $(P<0.05)$. Whereas half of the gonads were originally situated in the abdominal cavity in patients with expected no residual activity, one gonad was labial, and the rest were inguinal in patients with expected residual activity of AR. Labial or inguinal location of the gonads possibly contributed to relatively earlier clinical diagnosis and therefore earlier gonadectomy $(P<0.01)$ in our study; however, age of gonadectomy did not differ significantly $(P>0.05)$ between patients with and without expected residual activity of AR.

\section{Gonadal Histology Assessment}

Intertubular stroma appeared edematous (Figure 1a) mostly in younger patients, whereas in the older individuals it was rather fibrotic $(P<0.001$; Figure 1b). Combination of both edematous and fibrotic stromal changes within a single gonad was also observed, mainly in prepubertal patients. Areas of ovarian-like stroma (Figure 1c) were present in the gonads of one sibling pair (S4 and S9). Remarkably dilated lymphatic vessels (Figure 1d) were observed in $67 \%$ of gonads throughout the entire cohort. HNs (Figure 1e), ie, well-circumscribed nodules composed of Sertoli cell-only tubules and Leydig cells in between the tubules, were observed in all pubertal and postpubertal patients (13-year-old and older), and therefore, their development was significantly dependent on age $(P<0.001)$. Tubular atrophy presented as fibrosis of the tubules (Figure 1f) was observed in $47 \%$ of cases of patients older than 6 years of age and was significantly dependent on higher age $(P<0.001)$. Diffuse LCH (Figure 1g), which was present in all pubertal and postpubertal patients, was also dependent on older age $(P<0.001)$. Scattered Sertoli cells with eosinophilic granules in the cytoplasm (Figure 1h), so-called Hürtle cell-changes (a result of altered mitochondria), were identified in $14 \%$ of gonads, all in patients older than 9 years. Sertoli cell nodules, either with (Figure 1i) or without (Figure 1j) central hyaline deposits with partial calcification, were observed in almost $37 \%$ of patients, the youngest being 3-year-old.

In regard to signs of pubertal development, tubular lumen formation was evaluated and was not consistently present in any of the cases, although sporadic lumina (Figure 1k) were observed in the majority of the patients older than 9 years. Spermatogenesis was not encountered in any of the patients.

At least one tubule with germ cells was found in $84 \%$ of gonads. The number of tubules containing germ cells declined with age in the whole series $(P<0.001)$. A significant difference in germ cell survival $(P<0.05)$ between patients with and without 

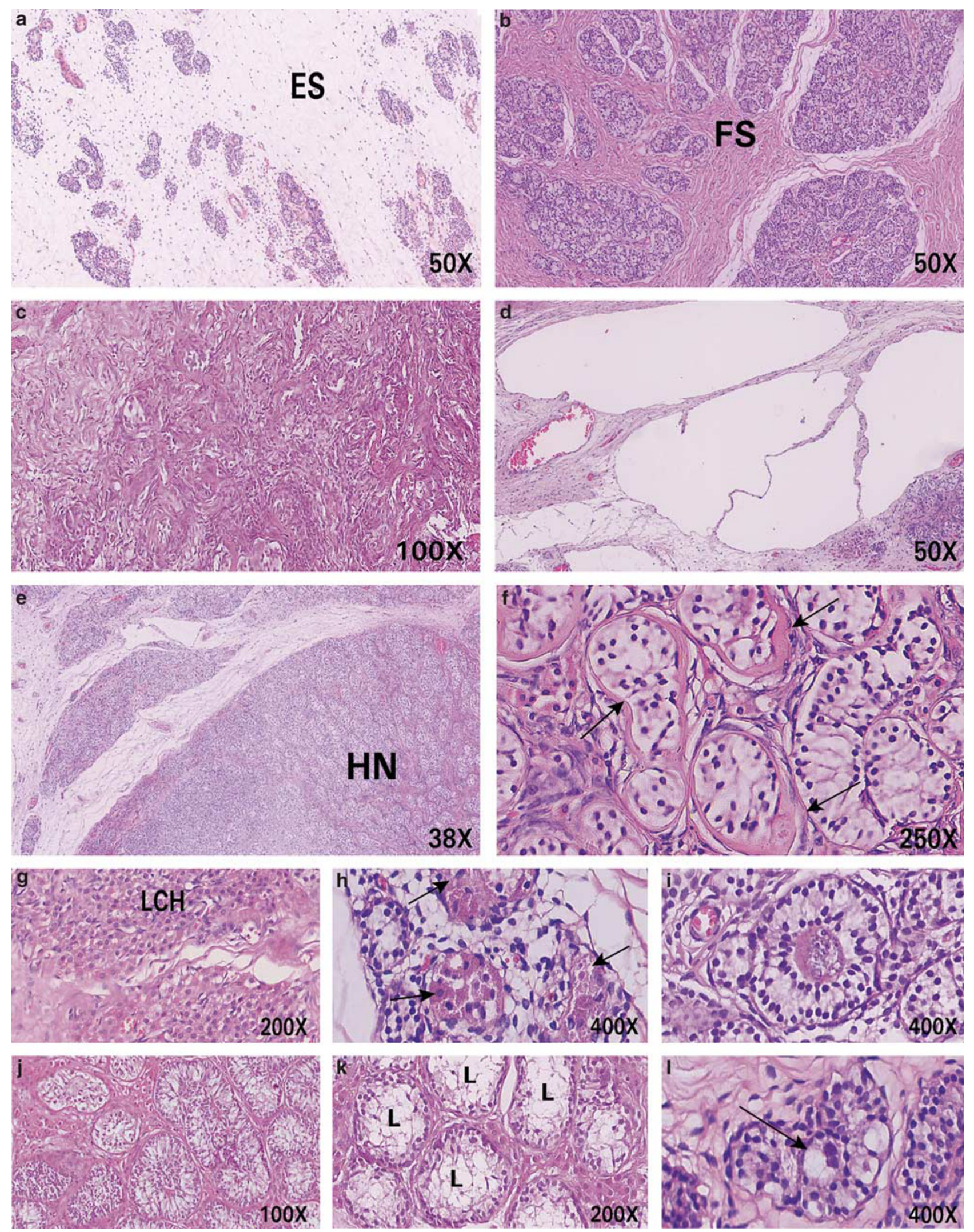

Figure 1 Different histopathological changes of the testis in complete androgen insensitivity syndrome, hematoxylin and eosin (H\&E) staining. (a) Edematous stroma (ES); (b) fibrotic stroma (FS); (c) ovarian-like stroma; (d) dilation of lymphatic vessels; (e) Hamartomatous nodule (HN); (f) fibrotic atrophy of the seminiferous tubules (arrow); (g) Leydig cell hyperplasia (LCH); (h) eosinophilic granular changes of Sertoli cell cytoplasm (arrow); (i) Sertoli cell nodule with central hyaline deposit; (j) Sertoli cell nodules without hyaline deposit; (k) sporadic lumen; (l) multinucleate germ cell (arrow). 
expected residual AR activity in (post)pubertal age was observed. Whereas the gonads of the patients with expected no residual activity lacked germ cells altogether or contained only solitary tubules with germ cells, a considerable number of tubules with germ cells was identified in patients with expected residual AR activity (Figure 2). Multinucleated germ cells (Figure 11) were found in almost two-thirds of gonads in which some germ cells remained. Gonadal location (abdominal versus inguinal) was not an independent influential factor in any of the above-described features when corrected for age and expected AR activity.

\section{Immunohistochemistry}

Cells showing POU5F1-positive staining were detected in 13/36 (35\%) gonads from 9/19 (47\%) patients (Table 2). A certain continuum in their distribution within the tubules was observed with increasing age. More than $85 \%$ of the positive cells were situated in the center of the tubules in four young patients (age 3 months to 3 years), bilaterally in two of them (Figure 3a). Positively stained cells were few in all cases, had round nuclei and were scattered throughout the whole gonad. They were TSPY1-negative or only slightly positive (Figure 3b). All the gonads were negative for KITLG (Figure 3c). Thus, the histochemical and morphological pattern resembled that of fetal gonads. ${ }^{14,26}$ The findings were classified as delayed maturation in three patients who were older than 6 months.

The earliest atypical features were identified in both of the gonads of a 6-year-old patient (S9). Up to $33 \%$ of the POU5F1-positive cells were attached to the basal lamina. Distribution throughout the testis was patchy with regions of several adjacent positive tubules. The cells were both TSPY1-negative and positive regardless the location within the tubules. In addition, the cells were morphologically atypical,

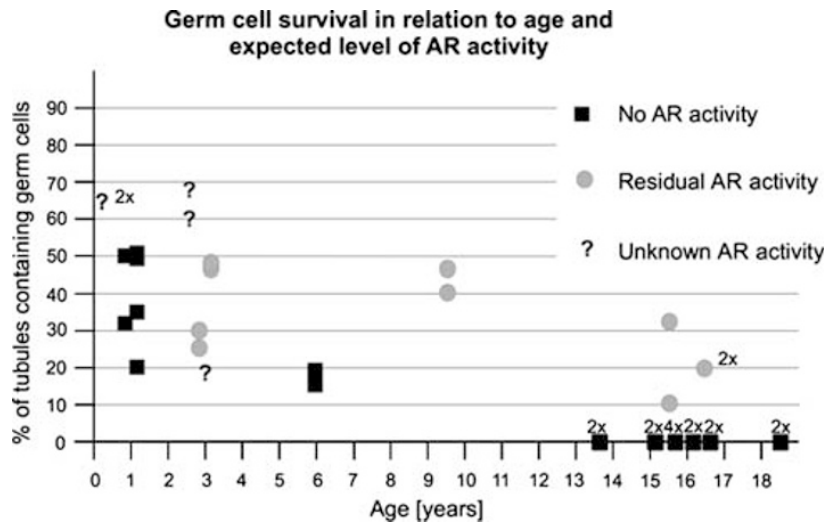

Figure 2 Germ cell survival in relation to age and expected level of AR activity. (a) Significant difference was observed in patients older than 13 years; almost no tubules with germ cells were present in patients with zero residual activity, whereas at least $11 \%$ of tubules containing germ cells were encountered in patients with expected residual AR activity. made obvious by the shape of the nuclei. Some nuclei were round, and others were irregular. Some of the areas with POU5F1-positive cells were KITLG-positive. However, there were also KITLGnegative tubules containing POU5F1-positive cells.

The changes were even more pronounced in the four oldest patients. POU5F1-positive cells occupied one well-circumscribed lobule in a 9-year-old patient (S10). Two-thirds of the cells were in contact with basal lamina (Figure 3d). The cells were very heterogeneous in morphology and staining pattern, again TSPY1-positive or TSPY1-negative in all locations (Figure 3e). KITLG expression was very strong in this case (Figure $3 \mathrm{f}$ ).

Several areas with POU5F1-positive cells were encountered in two 15-year-old twins (S14, S15), in both gonads in one of them. Interestingly, these were virtually the only regions with surviving germ cells (POU5F1-positive and negative) within the whole gonads. More than $60 \%$ of POU5F1-expressing cells were located at the periphery of the tubules, both positive and negative for TSPY1. KITLG expression was identified in most, but not all, regions.

As the germ cells were very heterogeneous in morphology and expression within particular tubules and because normal spermatogonial cells (ie, POU5F1-negative and TSPY1-positive) were often encountered in the same tubules as the atypical germ cells, a diagnosis of pre-intratubular germ cell neoplasia was made in patients S9, S10, S14, and S15.

According to the above criteria, intratubular germ cell neoplasia was present in one gonad of a 15-yearold patient (S13). More than $90 \%$ of the POU5F1positive cells were attached to the basal lamina (Figure 3g). Clonal expansion of germ cells, which were uniform in POU5F1 and TSPY1 expression, was observed in several tubules (Figure $3 \mathrm{~h}$ ). The expression of TSPY1 in POU5F1-positive germ cells was heterogeneous in other regions. KITLG expression was present in some, but not all, tubules with POU5F1-positive germ cells (Figure 3i). Many tubules contained exclusively normal spermatogonia (POU5F1-negative and TSPY1-positive) in this patient.

\section{Discussion}

According to current knowledge, two major factors influence postnatal testicular development: the location of the gonad and the androgen action..$^{2,3}$ Some histopathological changes, eg, HNs or LCH, develop during puberty as a consequence of the almost or entirely absent activity of androgens in complete androgen insensitivity syndrome. Other features, such as a decrease in germ cells, multinucleated germ cells, tubular atrophy, anomalous intertubular stroma, hyaline deposits, or lymphatic dilation, occur early in childhood. Therefore, their development is probably caused by 
Table 2 Results of immunohistochemical staining in POU5F1-positive gonads

\begin{tabular}{|c|c|c|c|c|c|c|c|}
\hline & $\begin{array}{c}\text { Age } \\
\text { (years) }\end{array}$ & Gonad & $\begin{array}{l}\% \text { Of POU5F1 } \\
\quad(+) G C \\
\text { attached to } B L\end{array}$ & KITLG & TSPY1 and POU5F1 double-staining & $\begin{array}{l}\text { Pattern of double- } \\
\text { staining }\end{array}$ & Overall evaluation \\
\hline \multirow[t]{2}{*}{ S1 } & 0.25 & Right & 0 & $(-)$ & $\begin{array}{l}\text { Most GC only TSPY1 (+); POU5F1 (+) GC are } \\
\text { mostly TSPY1 (-) }\end{array}$ & Homogeneous & $\begin{array}{l}\text { Normal } \\
\text { development }\end{array}$ \\
\hline & & Left & 3 & $(-)$ & $\begin{array}{l}\text { Most GC only TSPY1 (+); POU5F1 (+) GC are } \\
\text { mostly TSPY1 (-) }\end{array}$ & Homogeneous & $\begin{array}{l}\text { Normal } \\
\text { development }\end{array}$ \\
\hline S2 & 0.8 & Right & 8 & $(-)$ & $\begin{array}{l}\text { Most GC only TSPY1 (+); POU5F1 (+) GC are } \\
\text { mostly TSPY1 (-) }\end{array}$ & Homogeneous & Maturation delay \\
\hline S4 & 1.25 & Left & 6 & $(-)$ & $\begin{array}{l}\text { Most GC only TSPY1 (+); POU5F1 (+) GC are } \\
\text { mostly TSPY1 (-) }\end{array}$ & Homogeneous & Maturation delay \\
\hline \multirow[t]{2}{*}{ S8 } & 3.2 & Right & 13 & $(-)$ & $\begin{array}{l}\text { Most GC only TSPY1 (+); POU5F1 (+) GC are } \\
\text { mostly TSPY1 (-) }\end{array}$ & Homogeneous & Maturation delay \\
\hline & & Left & 11 & $(-)$ & $\begin{array}{l}\text { Most GC only TSPY1 (+); POU5F1 (+) GC are } \\
\text { mostly TSPY1 (-) }\end{array}$ & Homogeneous & Maturation delay \\
\hline \multirow[t]{2}{*}{ S9 } & 6.0 & Right & 33 & $(+)$ & $\begin{array}{l}\text { Most GC only TSPY1 (+); POU5F1 (+) GC are } \\
\text { both TSPY1 }(+) \text { and }(-)\end{array}$ & Heterogeneous & Pre-IGCNU \\
\hline & & Left & 19 & $(+)$ & $\begin{array}{l}\text { Most GC only TSPY1 }(+) \text {; POU5F1 }(+) \text { GC are } \\
\text { both TSPY1 }(+) \text { and }(-)\end{array}$ & Heterogeneous & Pre-IGCNU \\
\hline S10 & 9.5 & Left & 66 & $(+)$ & $\begin{array}{l}\text { Most GC only TSPY1 }(+) \text {; POU5F1 }(+) \text { GC are } \\
\text { both TSPY1 }(+) \text { and }(-)\end{array}$ & Heterogeneous & Pre-IGCNU \\
\hline S13 & 15.5 & Right & 93 & $(+)$ & $\begin{array}{l}\text { Many GC only TSPY1 }(+) \text {; POU5F1 }(+) \text { GC are } \\
\text { both TSPY1 }(+) \text { and }(-)\end{array}$ & $\begin{array}{l}\text { Homogeneous in } \\
\text { few Tubules }\end{array}$ & IGCNU \\
\hline S14 & 15.66 & Right & 61 & $(+)$ & $\begin{array}{l}\text { GC only in POU5F1 }(+) \text { areas, some only TSPY1 } \\
(+) \text {; POU5F1 }(+) \text { GC are both TSPY1 }(+) \text { and } \\
(-)\end{array}$ & Heterogeneous & Pre-IGCNU \\
\hline \multirow[t]{2}{*}{ S15 } & 15.66 & Right & 66 & $(+)$ & $\begin{array}{l}\text { GC only in POU5F1 }(+) \text { areas, some only TSPY1 } \\
(+) \text {; POU5F1 }(+) \text { GC are both TSPY1 }(+) \text { and } \\
(-)\end{array}$ & Heterogeneous & Pre-IGCNU \\
\hline & & Left & 69 & $(+)$ & $\begin{array}{l}\text { Many GC only TSPY } 1(+) \text {; POU5F1 (+) GC are } \\
\text { both TSPY1 }(+) \text { and }(-)\end{array}$ & Heterogeneous & Pre-IGCNU \\
\hline
\end{tabular}

Abbreviations: BL, basal lamina; GC, germ cells; IGCNU, intratubular germ cell neoplasia; (+), positive; (-), negative.

abnormal (inguinal or abdominal) location of the gonads, which commonly occurs in patients with complete androgen insensitivity. ${ }^{27}$ Differences in the effects of inguinal versus abdominal position of the gonads are difficult to assess because of an unequal age distribution of the study group, with inguinal gonads being more frequent in younger patients.

A positive impact of expected residual AR activity on the development of Wolffian duct structures and on the enlargement of seminiferous tubules after the onset of puberty in complete androgen insensitivity was described by Hannema et al. ${ }^{2,12}$ In addition, we observed a significant positive effect on nonmalignant germ cell survival after 13 years of age. Only single tubules containing germ cells were encountered in the gonads of patients with expected no residual activity of AR, whereas up to $34 \%$ of tubules of patients from the other group contained germ cells. No clear influence of expected residual AR activity was discovered on the other above-mentioned changes.

The survival of germ cells with fetal features (ie, POU5F1-positive) and their progression toward an invasive tumor in patients with complete androgen insensitivity syndrome are separate and very important issues. The level of risk for germ cell cancer development in complete androgen insensitivity remains a matter of debate. Manuel et al estimated the cumulative risk to be $3.6 \%$ at 25 years of age and $33 \%$ at 50 years of age. ${ }^{6}$ According to Deans et al, tumors occurred in $14 \%$ of adult patients based on historical literature. ${ }^{5}$ The risk was estimated to be $0.8 \%$ in another meta-analysis, but this estimation was mainly based on a group of patients in which gonadectomy was carried out during childhood. ${ }^{4}$ In fact, the risk is very difficult to predict because the approaches to manage patients with complete androgen insensitivity have continually changed over time. Whereas older reports included many adult patients and mainly reported the presence of invasive germ cell tumors, ${ }^{6,28,29}$ more recent studies on pediatric patients refer to pre-invasive lesions, ie, intratubular germ cell neoplasia, of the testis. ${ }^{2,8}$ Intratubular germ cell neoplasia is encountered mostly in pubertal or adolescent patients; ${ }^{2,8}$ however, the risk is calculated for entire patient groups that often include very young individuals in whom intratubular germ cell neoplasia has not had time to develop. Moreover, an intermediate stage between delayed maturation and adult type of intratubular germ cell neoplasia exists. ${ }^{8}$ Whether this lesion is predetermined to evolve into invasive cancer in all cases is unknown. In the general population, fully developed intratubular germ cell neoplasia is estimated to progress to an invasive tumor in 50\% of cases during 5 years, and its prevalence is similar to that of germ cell tumors, suggesting a $100 \%$ progression to invasiveness over time. ${ }^{30}$

We observed a developmental continuum between germ cells with delayed maturation and intratubular germ cell neoplasia in our study. POU5F1-positive and TSPY1-negative germ cells with round nuclei 

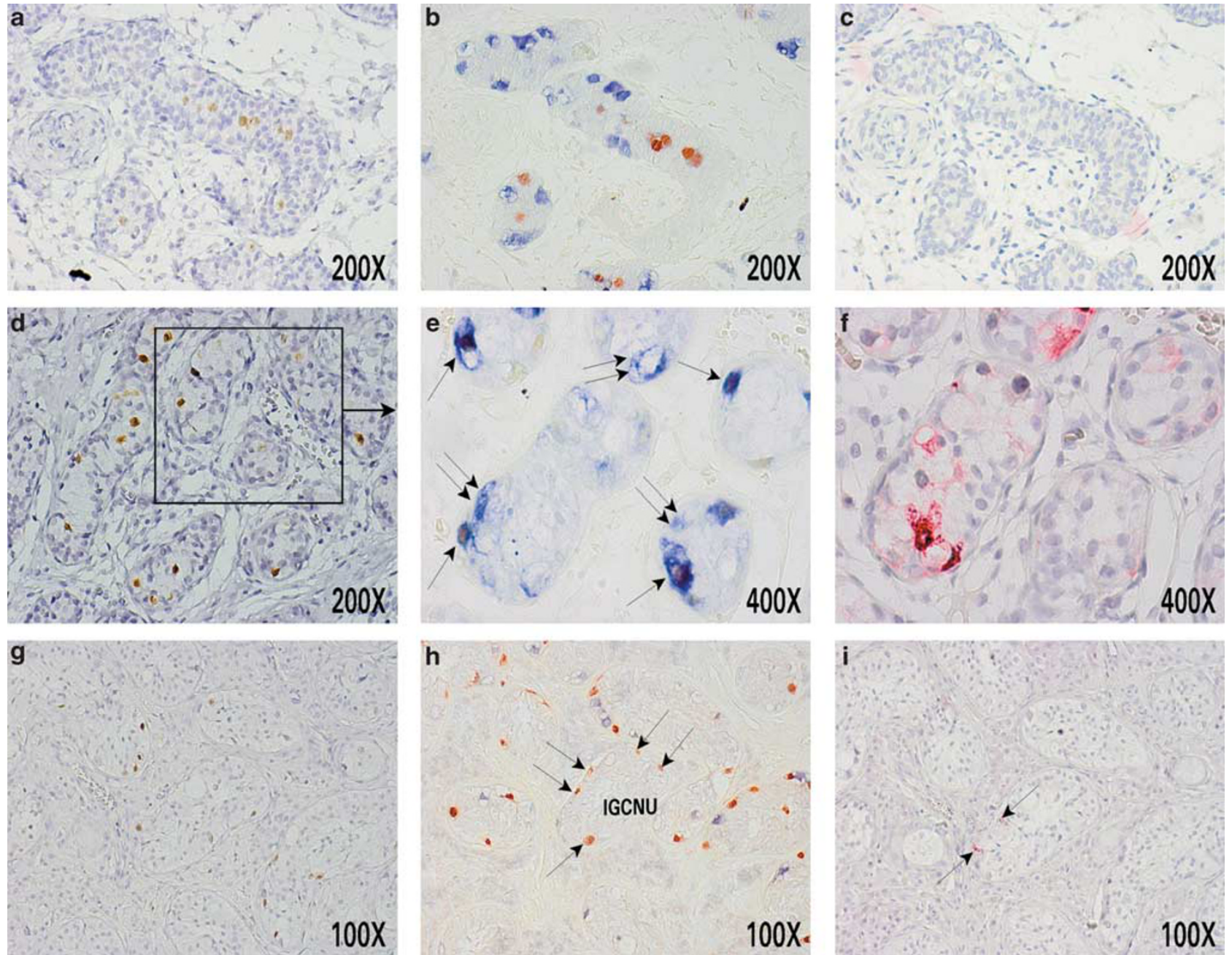

Figure 3 Immunohistochemical staining of gonads positive for POU5F1. (a) Delayed maturation POU5F1-positive germ cells (brown) all in the center of the tubules in a gonad from 10-month-old individual (S2); (b) same area as in a double-stained for POU5F1 (orange) and TSPY1 (blue) which are not co-expressed within the same cells; (c) same area as in a and b negative for KITLG; (d) pre-intratubular germ cell neoplasia, most of the POU5F1-positive germ cells are attached to the basal lamina in a gonad from 9-year-old individual (S10); (e) detail of the same area as in $\mathbf{d}$ double-stained for POU5F1 and TSPY1, heterogeneity of the germ cells within tubules, cells are either positive for both POU5F1 and TSPY1 (arrow) or only for TSPY1 (double arrow); (f) same area as in e strongly positive for KITLG (red); (g) intratubular germ cell neoplasia, almost all POU5F1-positive germ cells are attached to the basal lamina in a gonad from 15-year-old individual (S13); (h) same area as in g double stained for POU5F1 and TSPY1, seminiferous tubule (IGCNU) with a uniform population of germ cells, which are positive for POU5F1 only (arrow); (i) same area as in $\mathbf{g}$ and $\mathbf{h}$ stained for KITLG (positivity marked with arrow).

located in the center of the tubules, ie, immature germ cells, were identified in at least one gonad in four patients whose age ranged between 3 months and 3.2 years. Cools et al reported that some single POU5F1-positive germ cells are present in testes of normal individuals 6 months of age or younger. ${ }^{8}$ Nevertheless, if the youngest patient from our series is disregarded, three out of seven patients (43\%) between 6 months and 3.2 years of age carried germ cells with delayed maturation. POU5F1-positive germ cells with irregular nuclei attached to the basal lamina of the tubules, which in some cases were TSPY1-positive and located within KITLGpositive areas, were identified in at least one gonad in 5 out of 11 patients (45\%) older than 6 years of age. The lesion was classified as intratubular germ cell neoplasia in one case and as pre-intratubular germ cell neoplasia in the rest of the cases. Taken together, at least one gonad in 8 out of 18 (44\%) patients older than 6 months contained POU5F1positive germ cells, which may have given rise to an invasive tumor.

Regardless of whether we consider the proportion of the patients with (pre-)intratubular germ cell neoplasia among the older patients or the proportion of the patients older than 6 months with any kind of germ cell abnormality, the number of the gonads at risk is exceptionally high in comparison with other studies on pediatric patients. It is also high in comparison to cumulative risk for germ cell cancer in adult patients with complete androgen insensitivity (33\% in 50 years) estimated by Manuel. ${ }^{2,6,8}$ Such a high occurrence of atypical germ cells in our study may be incidental, but it may also indicate 
that not all abnormal germ cells will progress into an invasive tumor in patients with complete androgen insensitivity syndrome. We suspect two possible mechanisms that may explain the difference between the high prevalence of germ cell anomalies in this series of pediatric/adolescent cases and the much lower prevalence of invasive tumors in adults. The first is an absolute loss of the abnormal germ cells in adulthood when the gonads would have been retained. The second is a failure of progression of the pre-invasive lesions into an invasive cancer. Both mechanisms may be caused by a lack of androgen action in complete androgen insensitivity, resulting in a low-androgen environment. This lack-of-androgen theory would correlate with a significantly higher risk for tumor development in patients with partial androgen insensitivity syndrome $(15 \%$ versus $0.8 \%$ in complete androgen insensitivity syndrome according to Cools et al). ${ }^{4}$ Because we did not observe any significant differences in the persistence of POU5F1-positive germ cells and KITLG expression in relation to the expected level of AR activity among patients with complete androgen insensitivity syndrome, the residual activity of AR in complete androgen insensitivity is likely not powerful enough to achieve a similar effect on survival of abnormal germ cells and their progression into neoplasia as in partial androgen insensitivity. The result may be partly influenced by the relatively small sample size.

In conclusion, many histopathological changes in testis develop with increasing age and are mostly influenced by abnormal gonadal location (inguinal or abdominal) and impaired androgen action in patients with complete androgen insensitivity. An independent effect of inguinal versus abdominal position of the gonads is difficult to assess because inguinal gonads were present primarily in the youngest individuals. Expected residual AR activity contributes to better survival of the general germ cell population in (post)pubertal age; however, it did not seem to have an important role in the survival of POU5F1-positive germ cells and KITLG overexpression and thus appears to be unrelated to a higher cancer risk in patients with complete androgen insensitivity syndrome. Moreover, expected residual AR activity did not prevent the development of lack-of-androgen phenomena such as HNs and LCH. The high percentage of patients with germ cell abnormalities in our study suggests that most of the lesions do not progress to intratubular germ cell neoplasia and subsequent invasive germ cell tumors in complete androgen insensitivity. The level of risk in such cases remains to be elucidated. We observed one case with intratubular germ cell neoplasia and no invasive tumors in our study. This finding, together with other studies on pediatric patients, supports the current practice of postponing prophylactic gonadectomy to an adult age. ${ }^{1}$

\section{Acknowledgments}

This work was supported by an ESPE Research Fellowship granted by Novo Nordisk A/S and by the project (Ministry of Health, Czech Republic) for conceptual development of research organization 00064203 (University Hospital Motol, Prague, Czech Republic). MC is supported by the Flanders Research Foundation (FWO). Special thanks in memoriam to Dr Zuntova from Department of Pathology, University Hospital Motol, Prague, who collected the Czech samples and to Dr Lanska for statistical analysis.

\section{Disclosure/conflict of interest}

The authors declare no conflict of interest.

\section{References}

1 Hughes IA, Davies JD, Bunch TI, et al. Androgen insensitivity syndrome. Lancet 2012;380:419-428.

2 Hannema SE, Scott IS, Rajpert-De Meyts E, et al. Testicular development in the complete androgen insensitivity syndrome. J Pathol 2006;208:518-527.

3 Giwercman A, Bruun E, Frimodt-Møller C, et al. Prevalence of carcinoma in situ and other histopathological abnormalities in testes of men with a history of cryptorchidism. J Urol 1989;142:998-1001.

4 Cools M, Drop SLS, Wolffenbuttel KP, et al. Germ cell tumors in the intersex gonad: Old paths, new directions, moving frontiers. Endocr Rev 2006;27:468-484.

5 Deans R, Crighton SM, Liao L-M, et al. Timing of gonadectomy in adult women with complete androgen insensitivity syndrome (CAIS): patient preferences and clinical evidence. Clin Endocrinol (Oxf) 2012;76: 894-898.

6 Manuel M, Katayama KP, Jones HW. The age of occurance of gonadal tumors in intersex patients with Y chromosome. Am J Obstet Gynecol 1976;124:293-300.

7 Hurt WG, Bodurtha JN, McCall JB, et al. Seminoma in pubertal patient with androgen insensitivity syndrome. Am J Obstet Gynecol 1989;161:530-531.

8 Cools M, van Aerde K, Kersemaekers A-M, et al. Morphological and immunohistochemical differences between gonadal maturation delay and early germ cell neoplasia in patients with undervirilization syndromes. J Clin Endocrinol Metab 2005;90:5295-5303.

9 Bangsbøll S, Qvist I, Lebech PE, et al. Testicular feminization syndrome and associated gonadal tumors in Denmark. Acta Obstet Gynecol Scand 1992;71:63-66.

10 Cassio A, Cacciari E, D’Errico A, et al. Incidence of intratubular germ cell neoplasia in androgen insensitivity syndrome. Acta Endocrinol (Copenh) 1990;123:416-422.

11 Müller J, Skakkebaek NE. Testicular carcinoma in situ in children with the androgen insensitivity (testicular feminisation) syndrome. Br Med J 1984;288:1419-1420.

12 Hannema SE, Scott IS, Hodapp J, et al. Residual activity of mutant androgen receptors explains Wolffian duct development in the complete androgen insensitivity syndrome. J Clin Endocrinol Metab 2004; 89:5815-5822. 
13 de Jong J, Stoop H, Dohle GR, et al. Diagnostic value of OCT3/4 for pre-invasive and invasive testicular germ cell tumours. J Pathol 2005;206:242-249.

14 Stoop H, Honecker F, van de Geijn GJM, et al. Stem cell factor as a novel diagnostic marker for early malignant germ cells. J Pathol 2008;216:43-54.

15 Schnieders F, Dörk T, Arnemann J, et al. Testis-specific protein, Y encoded (TSPY) expression in testicular tissues. Hum Mol Genet 1996;5:1801-1807.

16 Brüggenwirth HT, Boehmer AL, Verleun-Mooijman $\mathrm{MC}$, et al. Molecular basis of androgen insensitivity. J Steroid Biochem Mol Biol 1996;58:569-575.

17 Brüggenwirth HT, Boehmer ALM, Lobaccaro JM, et al. Substitution of Ala564 in the first zinc cluster of the deoxyribonucleic acid (DNA)-binding domain of the androgen receptor by Asp, Asn, or Leu exerts differential effects on DNA binding. Endocrinology 1998; 139:103-110.

18 Mowszowitz I, Lee HJ, Chen HT, et al. A point mutation in the second zinc finger of the DNA-binding domain of the androgen receptor gene causes complete androgen insensitivity in two siblings with receptorpositive androgen resistence. Mol Endocrinol 1993; 7:861-869.

19 Weidemann W, Linck B, Haupt H, et al. Clinical and biochemical investigations and molecular analysis of subjects with mutations in the androgen receptor gene. Clin Endocrinol (Oxf.) 1996;45:733-739.

20 Beitel LK, Kazemi-Esfarjani $\mathrm{P}$, Kaufman $\mathrm{M}$, et al. Substitution of arginine-839 by cysteine or histidine in the androgen receptor causes different receptor phenotypes in cultured cells and coordinate degrees of clinical androgen resistence. J Clin Invest 1994;94: 546-554.

21 Knoke I, Allera A, Wieacker P. Significance of the CAG repeat lenght in the androgen receptor gene (AR) for the transactivation function of an M780I mutant AR. Hum Genet 1999;104:257-261.
22 Marcelli M, Zoppi S, Wilson CM, et al. Amino acid substitutions in the hormone-binding domain of the human androgen receptor alter the stability of the hormone receptor complex. J Clin Invest 1994;94:1642-1650.

23 Brüggenwirth HT, Boehmer ALM, Ramnarain S, et al. Molecular analysis of the androgen-receptor gene in a family with receptor-positive androgen insensitivity: an anusual type of intronic mutation. Am J Hum Genet 1997;61:1067-1077.

24 Zoppi S, Wilson CM, Harbison MD, et al. Complete testicular feminization caused by an amino-terminal truncation of the androgen receptor with downstream initiation. J Clin Invest 1993;91:1105-1112.

25 Oosterhuis JW, Stoop H, Dohle G, et al. A pathologist's view on the testis biopsy. Int J Androl 2011;34: e14-e19.

26 Honecker F, Stoop H, de Krijger RR, et al. Pathobiological implications of the expression of markers of testicular carcinoma in situ by fetal germ cells. J Pathol 2004;203:849-857.

27 Barthold JS, Kumasi-Rivers K, Upadhyay J, et al. Testicular position in the androgen insensitivity syndrome: implications for the role of androgens in testicular descent. J Urol 2000;164:497-501.

28 Morris JM, Mahesh VB. Further observation on the syndrome, "testicular feminization". Am J Obstet Gynecol 1963;87:731-745.

29 Rutgers JL, Scully RE. The androgen insensitivity syndrome (testicular feminization): a clinicopathologic study of 43 cases. Int J Gynecol Pathol 1991;10: 126-144.

30 Dieckmann K-P, Skakkebaek NE. Carcinoma in situ of the testis: review of biological and clinical features. Int J Cancer 1999;83:815-822.

31 Gottlieb B, Beitel LK, Nadarajah A, et al. The androgen receptor gene mutations database: 2012 update. Hum Mutat 2012;33:887-894. 